BUKHARI, A. I., AND TAYLOR, A. L. 1971. Mutants of Escherichia coli with a growth requirement for either lysine or pyridoxine. J. Bact., 105, 988-998.

MLLER, J. H. 1972. Experiments in Molecular Genetics. Cold Spring Harbor Laboratory, pp. 201-205.

SMrTH, D. A. 1961. Some aspects of the genetics of methionine-less mutants of Salmonella typhimurium. 7. Gen. Microbiol., 24, 335-353.

TAYLOR, A. L., AND TROTTER, C. D. 1972. Linkage map of Escherichia coli strain K12. Bact. Rev. 504-524.

\title{
MALE PARTHENOGENESIS IN TETRAPLOID JOB'S TEARS
}

\author{
PANUGANTI N. RAO \\ Department of Botany, Andhra University, Waltair, India
}

Received 4.xii.73

\begin{abstract}
SUMMARY
Male parthenogenesis was discovered in induced autotetraploid Job's tears, utilising a genetic marker for leaf hairiness, in natural crosses between recessive tetraploids and dominant diploids. In a progeny raised from seeds harvested from the diploid dominant parent one plant showed the recessive character of the tetraploid parent but diploid chromosome number indicating that this was derived through androgenesis in the tetraploid.
\end{abstract}

\section{INTRODUCTION}

Although the occurrence of male parthenogenesis has often been reported in diploid species (Kimber and Riley, 1963; Magoon and Khanna, 1963; Chase, 1969), information on its occurrence in autotetraploids is extremely scarce being restricted to the report of Davies (1958) in autotetraploid barley. In the present investigation, utilisation of genetic markers has afforded an opportunity to identify unexpectedly this apparently rare event in induced autotetraploid Job's tears (Coix lacryma-jobi L.) in an experiment conducted for quite a different purpose.

\section{Experimental materials}

Coix, like other Maydeae, is monoecious and naturally cross-pollinated. A strain of diploid Job's tears $(2 n=20)$, originally collected from plants that ran wild in the University Campus, and its colchicine induced autotetraploid $(4 n=40)$ are homozygous for certain qualitative characters (Campus Wild strain, table 1). These and another true-breeding strain $(2 n=20)$ with contrasting characters (Anantagiri strain, table 1), originally obtained from Anantagiri from a small colony of plants growing submerged along the margins of a hill stream at an altitude of 1000 metres, constituted the materials for this study.

Genetic analysis of the qualitative characters in crosses between the two contrasing diploids showed that purple seedling base and purple style are dominant over green seedling base and white style respectively and hairy leaf is incompletely dominant over glabrous leaf with the $F_{1}$ exhibiting short hairs (Venkateswarlu and Rao, unpublished). 
While false fruits of the tetraploid are large, spherical and brownishblack in colour, those of Campus Wild and Anantagiri strains are small and ovoid, their colour being bluish-white in the former, and brownish-black with whitish patches in the latter.

TABLE 1

Genetic characters of the Campus Wild (2n and $4 \mathrm{n}$ ) and Anantagiri (2n) strains of Job's tears

\begin{tabular}{|c|c|c|c|}
\hline \multirow{3}{*}{$\begin{array}{c}\text { Character } \\
\text { Seedling base colour }\end{array}$} & \multicolumn{2}{|c|}{ Campus Wild strain } & \multirow{2}{*}{$\begin{array}{c}\text { Anantagiri strain } \\
2 n\end{array}$} \\
\hline & $\stackrel{2 n}{2 n}$ & $\begin{array}{c}4 n \\
\text { Purnle }\end{array}$ & \\
\hline & $\begin{array}{l}\text { Purple } \\
\text { Purple }\end{array}$ & $\begin{array}{l}\text { Purple } \\
\text { Purple }\end{array}$ & $\begin{array}{l}\text { Green } \\
\text { White }\end{array}$ \\
\hline $\begin{array}{l}\text { 3. Hairs on the upper } \\
\text { surface of leaf }\end{array}$ & Glabrous & Glabrous & Long soft hairs \\
\hline
\end{tabular}

\section{Results}

In 1967, autotetraploids having the dominant traits of purple seedling base and purple style and recessive character of glabrous leaf, and diploids possessing the contrasting characters (Anantagiri strain) were grown in alternate rows in isolation. One way of rapidly screening for triploids through natural crossing between tetraploids and diploids, in an experiment like this, is to harvest seeds only from the diploid parent and raise the progeny. Individuals of this offspring showing dominant traits of the tetraploid would be triploids.

In the present investigation, since one of the genetic markers used was a seedling character, large progenies could be raised and scoring done in germinator trays or seed beds.

Several hundred seeds from the diploid rows were harvested by hand, and in June 1968, 800 of these were space planted in germinator trays filled with fresh sawdust. Five hundred and four seeds germinated of which 12 seedlings showed purple base. These were tentatively identified as triploids and removed to pots kept in the greenhouse. At maturity, 11 of these had purple style and short hairs on leaves, while the remaining plant showed purple style but glabrous leaves. Appearance of the recessive character in this aroused suspicion that it might have originated through androgenesis from the tetraploid male parent. The former 11 plants, on cytological study, revealed their triploid nature with chromosome numbers ranging from $3 n=31$ to 29 , but the glabrous plant showed a diploid number of $2 n=20$ with regular bivalent formation confirming its origin as an androgenic haploid (autopolyhaploid) from the autotetraploid by functioning of a male nucleus utilising the cytoplasm of the female gametophyte. While the seed set was low in triploids, it was quite high in the derived diploid. False fruits of the latter were small, ovoid and bluish-white in colour like those of the diploid Campus Wild strain. Since every care was taken in harvesting and sowing, the possibility that this derivative might be a contaminant or a self-sown seed of diploid Campus Wild strain was ruled out.

The occurrence of male parthenogenesis once out of only 12 gametes of the tetraploid tested led to the supposition that this might be a frequent phenomenon in tetraploid Job's tears. To verify this, the same experiment was repeated during 1968, this time removing male parts in the diploid 
female parent (Anantagiri strain) to facilitate testing of a much larger number of male gametes. But clipping of male spikelets in the female parent was discontinued about half way through the flowering season. From 28 diploid plants, a total of 4882 seeds have been harvested. These were space planted in seed beds in the following year. Of the 3038 seedlings developed from these, 342 showed purple base. All seedlings with green base, which were obviously the result of mating among individuals of the Anantagiri strain, were pulled out. Since glabrous condition of the leaf is the critical observation for detecting androgenesis, purple based seedlings were allowed to grow 4 to 8 weeks in the nurseries by which time the hairiness of leaf would be apparent. On examination all these plants had leaves with short hairs indicating that they were triploids. Non-occurrence of androgenesis in this experiment together with the unpublished information on interspecific crosses between $C$. aquatica $(n=5)$ and tetraploid Job's tears, with the latter as male, where also androgenesis was not observed reveals that male parthenogenesis in tetraploid Job's tears is not an event of frequent occurrence. Because of the gene markers involved, its chance occurrence in the first experiment could be identified which otherwise might have escaped attention.

Acknowledgments. - I am grateful to Professor J. Venkateswarlu for encouragement and facilities.

\title{
4. REFERENCES
}

chASE, s. s. 1969. Monoploids and monoploid-derivatives of maize (Zea mays L.). Bot.

Rev., 35, 117-167.

DAVIES, D. R. 1958. Male parthenogenesis in barley. Heredity, 12, 493-498.

KIMBER, G., AND RILEy, R. 1963. Haploid angiosperms. Bot. Rev., 29, 480-531.

MAGoON, M. L., AND KhaNNA, K. R. 1963. Haploids. Caryologia, 16, 191-235.

\section{NON-ALLELIC INTERACTION IN CONTINUOUS VARIATION OF RANDOMLY BREEDING POPULATIONS}

\author{
KENNETH MATHER \\ Department of Genetics, University of Birmingham
}

Received 25.i.74

\section{SUMmary}

The consequences are considered of digenic interactions for the variances and covariances commonly estimated from randomly breeding populations. The interaction affects the constitutions of $D_{R}$ and $H_{R}$ as well as introducing new quadratic terms by which, in principle, its presence can be detected. In practice the chief consequence of interaction is likely to be to alter the apparent values of $D_{R}$ and $H_{R}$ as estimated from the variances and covariances.

\section{Components of variation}

In the descendants of the cross between true breeding lines, or its equivalent, it has been shown that non-allelic interaction has a two-fold effect on the genetical components of continuous variation (see Mather and 